\title{
Wohltätigkeit, Selbsthilfe und organisierte Geselligkeit. Entwicklung, Funktion und Differenzierung des Vereinswesens
}

\begin{abstract}
Vereine entstanden ab dem späten i 8. Jahrhundert als ein Instrument, das den standesübergreifenden Zusammenschluss von Personen zur Erfüllung eines bestimmten Zweckes ermöglichte, und lösten frühere Organisationsformen wie etwa Korporationen zunehmend ab. Auf Basis bestehender Literatur und theoretischer Ansätze aus der historischen und soziologischen Vereinsforschung werden Funktionen von Vereinen diskutiert und eine typologische Gliederung in Vereine mit öffentlichem Zweck, Selbsthilfevereine und Freizeitvereine vorgestellt. Die Differenzierung des Vereinswesens und seine rasante quantitative Entwicklung im letzten Drittel des I9. Jahrhunderts verdeutlichen das Ausmaß der gesamtgesellschaftlichen Bedeutung, die Vereine erreichten. Durch den exemplarischen Blick auf die Vereinslandschaft der niederösterreichischen Kleinstadt Zwettl zeigt sich die dynamische Interaktion zwischen Vereinen und Verwaltungsbehörden und die Entwicklung von Vereinen zu wichtigen Akteuren innerhalb einer lokalen Öffentlichkeit.
\end{abstract}

Charity, Self-Help and Organized Sociality. Development, Function and Differentiation of Associations. Associations emerged from the late $\mathrm{i} 8^{\text {th }}$ century onwards as a form that enabled people from different social classes to come together to fulfil a specific purpose, thus increasingly replacing earlier forms of organisation such as corporations. On the basis of existing literature and theoretical approaches from historical and sociological research, the chapter discusses the functions of associations and presents a typological classification as associations with a public purpose, selfhelp associations and leisure associations. The differentiation between associations and their rapid quantitative development in the last third of the $19^{\text {th }}$ century illustrate the extent of the overall social importance associations achieved. The exemplary view of the associations in the small Lower Austrian town of Zwettl shows the dynamic interaction between associations and administrative authorities and their development into important actors in the local public sphere.

Keywords: voluntary associations, sociability, public sphere, self-organization, infrastructural power

doi.org/10.52035/noil.2021.19jh02.13

Veröffentlicht nach externer Begutachtung (doppelblind) / published after external peer review (double blind) 